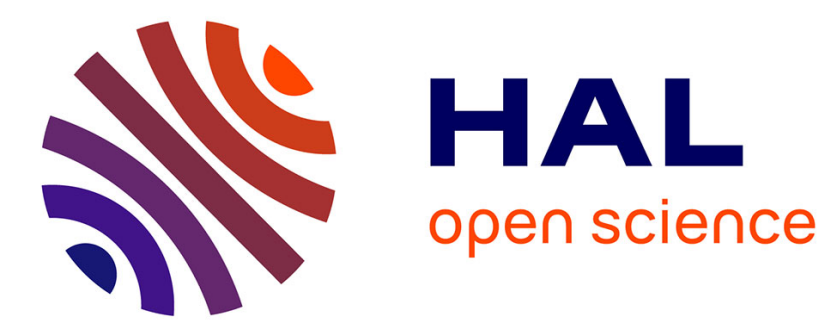

\title{
Alternative visions: permaculture as imaginaries of the anthropocene
}

Anahid Roux-Rosier, Ricardo Azambuja, Gazi Islam

\section{To cite this version:}

Anahid Roux-Rosier, Ricardo Azambuja, Gazi Islam. Alternative visions: permaculture as imaginaries of the anthropocene. Organization, 2018, 25 (4), pp.550-572. 10.1177/1350508418778647 . halshs-01958956

\section{HAL Id: halshs-01958956 \\ https://shs.hal.science/halshs-01958956}

Submitted on 18 Dec 2018

HAL is a multi-disciplinary open access archive for the deposit and dissemination of scientific research documents, whether they are published or not. The documents may come from teaching and research institutions in France or abroad, or from public or private research centers.
L'archive ouverte pluridisciplinaire HAL, est destinée au dépôt et à la diffusion de documents scientifiques de niveau recherche, publiés ou non, émanant des établissements d'enseignement et de recherche français ou étrangers, des laboratoires publics ou privés. 
running head: IMAGINARIES OF THE ANTHROPOCENE

\title{
Alternative Visions: Permaculture as Imaginaries of the Anthropocene
}

Roux-Rosier, A., Azambuja, R. \& Islam, G. (2018) Alternative Visions: Permaculture as imaginaries of the Anthropocene. Organization, 25(4),550-572.

\begin{abstract}
The current paper uses the concept of imaginaries to understand how permaculture provides alternative ways of organizing in response to the Anthropocene. We argue that imaginaries provide ways of organizing that combine ideas and concrete practices, imagining organizational alternatives by enacting new forms of collective practice. Permaculture movements, because of their combination of local, situated design practices and underlying social and political philosophies, provide an interesting case of imaginaries that make it possible to reimagine the relations between humans, non-human species and the natural environment. We identify and describe three imaginaries found in permaculture movements, conceiving of permaculture respectively as a technical design practice, a holistic life philosophy, and an intersectional social movement. These imaginaries open up possibilities for political and social alternatives to industrially organized agriculture, but are also at risk of various forms of ideological co-optation based on their underlying social premises. We discuss our perspective in terms of developing the concept of imaginaries in relation to organizational scholarship, particularly in contexts where fundamental relations between humans and the natural environment must be reimagined, as in the case of environmentalist organizing in response to the Anthropocene.
\end{abstract}

\section{Key-words}

Anthropocene, Permaculture, Imaginaries, Social Imaginaries, Organizing, Collective, Environmental Imaginaries. 
The imagination is now central to all forms of agency, is itself a social fact, and is the key component of the new global order Appadurai, 1990, p. 5

Imagining anthropogenic climate change, and its related ecological and social transformations, has opened avenues for the promotion of new forms of relations between humans and their environment (Gosling and Case, 2013; Wright, Nyberg, De Cock and Whiteman, 2013). From ontological questions about nature and the human (Chakrabarty, 2009; Viveiros de Castro, 2015) to struggles over imagined futures based on fossil fuels, technological fixes, or sustainable lifestyles (Levy and Spicer, 2013), struggles over social imaginaries have been at the heart of difficulties in addressing climate change (Wright et al, 2013).

Imaginaries, as theorized in Castoriadis (1987/1975), comprise evolving systems of symbols and meanings that enable agency and shape social and economic systems (cf. Gaonkar, 2002; Jessop, 2010; Yusoff and Gabrys, 2011). Imaginaries arise out of spaces created in moments of crisis or uncertainty (Castoriadis, 1987/1975; Zanoni et al., 2017), and projections regarding the catastrophic ecological consequences of industrialized human activity constitute precisely such a moment (Chakrabarty, 2009). The paucity of attention around imaginaries in the Anthropocene has hindered adequate organizational responses (Wright et al., 2013); specifically, dislodging techno-scientific hegemonies in this area requires imagining and dreaming alternative possible futures (Gosling and Case, 2013). Given the possibly cataclysmic futures awaiting human societies in the Anthropocene, such social imaginaries are an important source of organizing potential in response to the need to adapt in the face of the threat these potential futures pose.

Against the prospect of ecological crisis and the looming threat of environmental degradation, organizations have actively constructed organizational responses to climate 
change (e.g. Nyberg and Wright, 2016; Whiteman et al., 2013) and emphasized the importance of imagining new ways of living in nature (e.g. Gosling and Case, 2013; Laine, 2010; Perey, 2016). As a way of recasting humans' role in nature, the Anthropocene describes a geological epoch determined by the impact of human activity, foregrounding human beings as a significant geological actor (Crutzen, 2002; Steffen et al., 2007; Steffen et al., 2011). Reimagining human-nature relations, and presenting scenarios that are both uncertain and highly urgent, the Anthropocene demands new imaginings of organizational futures (Gosling and Case, 2013; Heikkurinen et al., 2015; Wright et al., 2013). Attempts to create field-level narratives around these scenarios have largely failed, and heterogeneous environmental discourses have emerged from these attempts (Schüßler et al., 2014).

In the politically and ideologically charged context of the Anthropocene, alternative imaginaries performatively construct visions of humans and the environment (Escobar, 1999; Nyberg and Wright, 2016), presenting opportunities for scholars to critically examine and evaluate these visions. Two key problematics arise around the emergence of such imaginaries in the Anthropocene. First, because even the most utopian organizational imaginings draw upon existing discourses and images (cf. Canavan and Robinson, 2014), alternative imaginaries may reproduce existing ideologies in their very articulations of change. Second, because imaginaries influence concrete practices of inhabiting the Earth, their material and embodied aspect is particularly salient. In the context of ecological discourses, the separation between material practice and abstract theory is problematized (cf. Haenn and Wilk, 2006), highlighting the material dimension of imaginaries (Medeiros et al., 2017) and their entanglement with concrete practices (Appadurai, 2016). These two problematics highlight the possibility that, firstly, 
alternative imaginaries may be recruited by dominant actors to reproduce, rather than challenge, hegemony (Zanoni et al., 2017), and, secondly, that the construction of imaginaries is subject to a materiality that has been neglected in past research.

As a paradigmatic example of the intertwining of material practice and ideological ambivalence, we focus on the agricultural and land-use organizing termed 'permaculture' (Ferguson and Lovell, 2014; Holmgren, 2002; Mollison, 1994). Permaculture comprises a diverse set of practices defying narrow definition (Holmgren, 2002), carefully cultivating values of informality, heterogeneity and non-institutionalization (Ferguson and Lovell, 2014). These aspects make permaculture particularly fruitful as a source of imaginaries, as its network of practitioners insist on the persistence of localized experimentation (Mollison, 1994). Permaculture produces alternative environmental imaginaries of the Anthropocene that are worth examining for several reasons. First, given that the Anthropocene calls into question what we might term 'classical' humannature relations (e.g. Chakrabarty, 2009; Viveiros de Castro, 2015), organizational modalities leaning heavily on the human-nature interface are ideal sites for the study of imaginaries responding to the concerns of the Anthropocene (Lockyer and Veteto, 2013). Second, the lack of a unified permaculture 'movement' and the emphasis on differentiated, localized solutions (Lockyer and Veteto, 2013; Mannen et al., 2012), promotes heterogeneous forms of permaculture, allowing for an examination of the diverse ways of imagining sustainable earth habitation. Third, this diversity permits a critical assessment of the ambivalent political stakes of permaculture solutions, with the aim of arriving at an understanding which can more broadly inform organizational responses to environmental changes. 
To ground our conceptual analysis, we begin with the research question: How do alternative organizational imaginaries embodied in permaculture initiatives re-imagine ways of inhabiting the Earth in the Anthropocene? We begin by conceptually exploring the importance of imaginaries in creating organizational alternatives in the Anthropocene, and then illustrate such imaginaries through extended investigations of examples of permaculture initiatives. Our objective is not to engage in an empirical study of permaculture movements, but to use existing discussions of permaculture (e.g. Ferguson and Lovell, 2014; Lockyer and Veteto, 2013) to illustrate the wider issue of organizational imaginaries in the Anthropocene. Through such an illustration, we critically evaluate and theorize how organizational responses can articulate new imaginaries of inhabiting the earth, and also how these imaginaries can rearticulate dominant ideological positions even as they attempt to challenge the status quo.

After conceptually unpacking the notion of imaginaries in this way, we develop our contribution by noting the neglected roles of materiality and ideological ambivalence, as actors promote different ways of thinking and enacting imagined communities. Linking these problems to current thinking on permaculture, we examine how different permaculture imaginaries reflect heterogeneous utopian conceptions of human habitation. Specifically, we examine permaculture as a set of practices, as a socio-political movement, and as a philosophical life transformation. For each imaginary, we consider critical and transformative, as well as ideological and normative underpinnings. Given the paucity of organizational examinations of permaculture specifically (e.g. Mannen et al., 2012) and the Anthropocene more generally (e.g. Alcaraz et al., 2016), we then conclude by laying out directions for future research based on our theorizing. 


\section{Imagining the Anthropocene}

Attempts to imagine new ways of organizing face the inherent problem of acting on the basis of a reality that, by definition, does not yet exist (cf. Parker et al., 2007). As utopian projects, such attempts require agents to imagine and enact new ways of being and to performatively realize these forms in practice (Gaonkar, 2002; Schechner, 2015), both affirming actors' agency (Milkoreit, 2017) while, at the same time, shaking off current institutional supports for agency - a seeming paradox. Following Castoriadis (1987/1975), Gaonkar (2002: 1) describes imaginaries as "enabling but not fully explicable", able to support new forms of subjectivity but with consequences that are not fully known. More obviously than with discourses or logics, they rely on a projection into an unknown future. Similarly, imaginaries rely on a fundamental indeterminacy in their meanings (Wright et al., 2013); this means that, more than struggles over meanings or logics, building imaginaries mixes utopian dreaming (Gosling and Case, 2013), discourse, and concrete action (Appadurai, 1990). In Appadurai's (1990: 5) words, such a view takes "the imagination as social practice".

The prefigurative and performative aspects of imaginaries have theoretical implications that have not been adequately addressed in organizational scholarship. One such implication results from the consequences of Appadurai's (1990: 5) claim that contemporary imaginaries are "no longer mere fantasy," but are instead a "form of work" that is both material and cultural. Echoing this "materialization" of imaginaries (Medeiros et al., 2017), scholars have noted how contemporary imaginaries are bounded by material and technological constraints (Kohl and Farthing, 2012) and exist within politically grounded conceptions of space and land (Wolf, 2004). In the Anthropocene, the ecological, and even the genetic, aspects of species-being are shaped through technical 
and sociological imaginaries and their technological practices (Dillon and LoboGuerrero, 2009; Fujimora, 2003). It is not surprising, in this context, that Dillon and Lobo-Guerrero (2009: 2) define imaginaries as the "ontological specification of the nature of being", framing the imaginary not in opposition to the real, but as a modality of the real. In this context, the imaginary is as much an ecological as it is an ideological concept, articulating nature with culture.

Moreover, this materialization of imaginaries in social practices raises the stakes for their ideological co-optation and appropriation, as dominant ideologies are embedded into the very material structure of environments, inter-species relationships, and even the bodies of organisms themselves (e.g. Haraway, 1997). In this context, imaginaries have concrete effects, and one of the consequences of the Anthropocene is an acknowledgement of the material consequences of a given culture. Such a unification of nature and culture has, historically, marked the discourse of utopian movements as alternatives to modernity and capitalism (Milkoreit, 2017); yet, a considerable part of the difficulty of imagining or enacting such alternatives lies precisely in the fact that dominant institutions are deeply embedded into the structure of the environment itself and that, as such, it will be difficult for any alternative imaginaries or practices to resist subsumption by dominant ideologies.

Indeed, critical management studies (CMS) scholarship has noted how contested imaginaries around climate change have been corralled into ways of thinking that can impede change (Levy and Spicer, 2013). Corporate actors domesticate environmental discourses to fit them into a market-friendly, "business-as-usual" paradigm (e.g. Nyberg and Wright, 2016; Wright and Nyberg, 2015). On the other hand, scholars have acknowledged the need for alternative imaginaries that can mobilize collective action 
towards visions of radically new organizational futures (Gosling and Case, 2013; Lockyer and Veteto, 2013; Wright et al., 2013). Scholars have noted that climate change in particular requires news forms of social imagination (Wright et al., 2013), but we know less about how different imaginaries are performed in concrete practices that entrench underlying worldviews.

\section{Anthropocene as Contested Imaginaries}

In the early 2000s, Crutzen and Stoermer suggested that the geological era of the Holocene had given way to what they termed the "Anthropocene". Foregrounding the human being - "Anthropos" - as the principal determinant and prominent element of this switch, they highlighted the geological scale of human impacts (Crutzen, 2002; Steffen, et al., 2007; Steffen et al., 2011). Symptomatic of this shift was a profound deterioration of the biosphere (Zalasiewicz et al., 2011), a development whose manifestations include the degradation of ecosystems and of the bio-geochemical cycles of water, nitrogen and phosphate, a significant decrease in biodiversity (Barnosky et al., 2011), and a massive increase in pollution in the atmosphere, soil, and continental and ocean waters.

The Anthropocene concept sought to make intelligible the union between the geological history of the planet (understood as the Earth-system), the history of life (as an evolutionary process), and the history of human civilization (Chakrabarty, 2014). Building a temporal narrative out of the impacts of the human appropriation of nature (Federau, 2017), the concept invited humans to imagine the Earth-system as a chronological and dynamic organization composed of interrelated actors.

Critical scholarship, however, has questioned the species-based focus on Anthropos as unjustly generalizing across the human species what is fundamentally a result of capitalism (Fraser, 2014; Malm and Hornborg, 2014) with its associated power differences and injustices (Moore, 2016; Palsson et al., 2013;). Critical and historically- 
oriented approaches note diverse modes in which human societies relate to their environments (Descola, 2005). Moreover, the environmental implications of human activity involves contested imaginaries (Levy and Spicer, 2013), which have different implications for organizational responses to the Anthropocene. In this narrative, it is not humanity in general, but a specific human-biosphere organization characteristic of capitalism and of a certain modernist philosophy, that characterizes the Anthropocene (Larrère and Larrère, 2009; Naess, 1989). Accordingly, the concept of an essentialized Anthropos (Schlosberg, 2016) is rejected. In short, such views consider the Anthropocene as an organizational problem, not an inherent vice of humanity.

Critical perspectives draw parallels between the Anthropocene and wider critiques of capitalism, as the exploitation formerly reserved for relations of production is applied to the appropriation and reproduction of natural ecosystems themselves (e.g. Foster, 2000; Fraser, 2014; Kallis, 2011; Martinez-Alier et al., 2014). Fraser (2014) notes that classical versions of critical theory often overlooked the "hidden abodes" of exploitation beyond the workshop. Even when, as in Polanyi (2001/1944), the unsustainable exploitation of land is acknowledged, recourse is sought in essentialist visions of nature (Escobar, 1999) that obscure the socially constructed nature of human landscapes (Fraser, 2014: 67). Industrial production separated human economies from the cycles of nature, colonizing and channelling natural systems according to ever-accelerating rhythms of capital accumulation, decoupling productive organization from the more glacial rhythms of natural recuperation, in what Marx (and later Polanyi) referred to as a "metabolic rift." (Foster, 1999).

\section{Organizing New Imaginaries}

In response to the "rift" between the organization of industrial production and the rhythms of ecological regeneration, organizing to realign human and ecological rhythms 
involves reimagining human-environment relationships so as to suggest new ways of inhabiting the Earth (Moore, 2016; Gosling and Case, 2013; Laine, 2010). Organizing new approaches to co-habitation and global integration into the Earth-system, such imaginaries would acknowledge actual and possible destructive human global impacts while seeking new visions of co-habitation with other natural beings.

For instance, Gosling and Case (2013) suggest that "future imaginings" may be supported by "social dreaming", a collective utopian imagination going beyond individual dreaming. Conversely, Nyberg and Wright (2015) show how corporations fight back against ecological discourses by subsuming them into market-friendly discourses of risk. Such contests between imaginaries (Levy and Spicer, 2013) determine how the environment is imagined, narrated or 'dreamed' in ways that suggest a struggle over provinces of meaning and their related practices.

Seeing such imaginaries as central for a critical theory of the Anthropocene, Moore (2016: 3) argues that "efforts to transcend capitalism in any egalitarian and broadly sustainable fashion will be stymied so long as the radical political imagination is captive to capitalism's either/or organization of reality: Nature/Society". That is, social and environmental justice is only achievable through imaginaries that transgress this dualistic ontology, contesting not only the distribution of the capitalist 'order of things', but also its organization, by exposing it as an arbitrary choice. In short, understanding the Anthropocene requires an examination of the diverse imaginaries that actors construct and apply in their organizing practices.

\section{Imaginaries of Permanent (Agri)culture}

Permaculture constitutes an ideal case to investigate organizational responses to the Anthropocene because, as a form of agricultural organization, it describes a 
fundamental human activity that both stands at the core of social structures and is necessary for human survival and reproduction (McIntyre et al., 2009). Agriculture both represents symbolic relationships between human societies and nature (Serres, 2001) and materializes how humans organize and manage nature. It contributes significantly to human impact on Earth and is, in turn, strongly affected by climatic change (Howden et al., 2007; McIntyre et al., 2009; Rickards and Howden, 2012). Current ecological crises, moreover, call for a re-organization of land-use and food production (Godfray et al., 2010, Leclère et al., 2014). Thus, because the Anthropocene puts into question the humannature relation, it is intuitive that agricultural production is one of the first sites of organizational response.

Permaculture, derived from 'permanent' and 'agriculture,' is an agricultural practice commonly associated with agroecological movements (McIntyre et al., 2009; Fergusson and Lovell, 2014; Pant, 2016). Originally theorized by Bill Mollison and David Holmgren in the 1970s and 1980s, its principles and practices are largely informal, heterogeneous and un-institutionalized, spreading across networks of practitioners (Ferguson and Lovell, 2014; Holmgren, 2002). In its overarching perspective, permaculture aims to organize the human process of the domestication of ecosystems through the conception of "complete agricultural ecosystems," defined as "evolving, integrated system(s) of self-perpetuation of plant and animal species useful to man [sic]" (Mollison and Holmgren, 1978: 15). Permaculture has been described as a "holistic, integrated practice that can build functioning sustainable alternatives that balance the needs of nature with the needs of humans" (Pickerill, 2013: 100). Thus, although definitions are intentionally broad, permaculture organizing can be characterized by its conscious attention to design, its mimicry of ecological patterns, its claim to yield usable 
resources and beings at the local level, and its recuperation of traditional agro-ecological practices (Holmgren, 2002; Mannen et al., 2012).

As a source of imaginaries, permaculture hybridizes aspects of agricultural practices, ecology, social justice, utopian and mythic worldviews (cf. Yusoff and Gabrys, 2011) to frame alternative social constructions of the human-nature relation. Some of these imaginaries have been influenced by indigenous land-use practices and worldviews (Mollison, 1979, 1994; Mollison and Holmgren, 1978) - for instance, Australian Aboriginal myths of dreaming involving place-based imaginaries (Mollison, 1979, 1988) where living entities are familiarly related and connected through duties of mutual care. As a mode of organizing, permaculture draws upon concepts of pattern reading and design, ideals of co-habitation and relationality, and the integration of places, living systems and global land-use (Lockyer and Veteto, 2013; Mollison, 1994).

Managing a permaculture system, meanwhile, consists in continuously observing and stabilizing the ever-changing interactions between the natural beings within it (Mollison and Holmgren, 1978). Disease and other difficulties experienced by organisms within the system are seen as symptoms of design misconceptions, revealing a lack of stabilizing elements. Problems are usually addressed through integrating functional regulative beings: if bees are killed by Asian wasps, for example, it is preferable to introduce chickens to hunt the wasps - thus also meeting the chickens' need for proteins - than to spray synthetic chemical pesticides. Organizing permaculture agro-systems involves managing relationships between diverse biological entities, each of which is considered according to the complete range of functions it can enact within the system. For example, in the association corn/bean/squash, each of the plants has at least one purpose: providing food (to the designer, i.e. humans). Cultivated together, however, each 
also provides a helpful presence for the other two: bean roots provide nitrogen for the other plants, corn offers a helpful stalk for the bean to grow and attain sunlight, and squash leaves, forming a canopy over the ground, help regulate soil humidity and slow the development of competitor plants. Moreover, all three are linked to a wider range of entities, inter alia, as a source of food (e.g. pollen for bees) and shelter (e.g. humid and dark under-leaf mulch for slow-worms - the same slow-worms that eat slugs). The corn/beans/squash triad, dating from long before permaculture and known by indigenous groups such as the Haudenosaunee (Wilson, 2004), is a good example of how traditional knowledge can be reimagined in terms of agricultural system-design as an alternative to industrial agriculture.

In short, by supporting a "dialogue between man [sic] and natural factors" (Mollison and Holmgren, 1978: 9), permaculture practices build imaginaries of community across human and non-human boundaries. The communities are imagined as multi-species collectives (Descola, 2017), based on specific design principles and organizing schema for the management of anthropized spaces.

\section{Permaculture Imaginaries: Practices, Life Philosophy, Social Movements}

Based on the above characterization of permaculture, we can discern in broad outlines a focus on practice and design, a holistic and cosmic concern with harmony and unity (Veteto and Lockyer, 2013), and a preoccupation with intersectional concerns linking social and environmental movements. Although these concerns are interspersed throughout permaculture writings and initiatives, we highlight them as distinct imaginaries driving permaculture initiatives, and thus as sources of heterogeneity within the permaculture tradition. The lack of rigorous empirical study of permaculture in the social sciences (Veteto and Lockyer, 2013) means that any attempt at characterization is 
provisional; empirical work within and across these initiatives is required to establish any taxonomy with certainty. However, our goal in the current paper is not to provide an empirical catalogue of taxonomies, but rather to demonstrate the diversity of organizational concerns related to the Anthropocene.

Thus, we stress that most permaculture writings and initiatives contain elements of practice, an emphasis on holism (a word which, by our count, appears, along with its derivatives, 149 times in Lockyer and Veteto's (2013) edited collection on permaculture), and concerns with social movements. These can be formalized as a set of imaginaries, which we characterize as: a) Permaculture as a Set of Practices; b) Permaculture as a Holistic Life Philosophy; and c) Permaculture as an Intersectional Social Movement. These imaginaries may not always be in harmony: for instance, emphasizing holistic Earth-level change (holistic life philosophy) along with small-scale local action (set of practices), if not in tension, would at least beg further explanation, as would emphasizing the relation between environmental and social movements while simultaneously questioning the distinction between society and nature. While aspects of each kind of imaginary may be present in the others, each also implies certain kinds of relations between the entities within a permaculture system, as well as imagined relations between social ideals and material co-habitation (Yusoff and Gabrys, 2011).

Table 1 illustrates the general outlines of these permaculture imaginaries, summarizing their technical, philosophical, social and political tendencies and noting some examples described in the literature. We describe each according to an overarching "manifest imaginary" that characterizes each as practice, philosophy, or social movement. However, each of these imaginaries also suggest "latent" utopian images that aliment and motivate each imaginary. For instance, while the imaginary of "practices" draws on latent 
visions of autonomy, or working the earth, the "life philosophy" imaginary is motivated by visions of harmony and unity, and the "social movement" imaginary, by visions of resistance and political emancipation. Each imaginary operates at a different scale of conception - whether local or global; each frames a different relation to theory and practice; finally, each encapsulates diverse visions of the boundary between human and other natural beings in their environment.

As noted above, a given permaculture initiative is likely to contain elements of all three imaginaries. Their combinations may strive for coherence or co-exist in an uneasy bricolage, with aspects of one upstaging or occluding the others. To illustrate how this could work in practice, Table 1 gives some examples from the empirical literature of permaculture initiatives that tend toward one or the other imaginary. Below, we discuss each of the three imaginaries, with their respective examples.

Permaculture as a Set of Practices

Permaculture initiatives are often marked by a strong tendency toward local, practicable knowledge that can be used to plan and cultivate agricultural systems. These systems integrate diverse human and non-human actors into a collective constructed by the "designer(s)" (e.g. Mollison, 1979; Mollison and Holmgren, 1978). The designers plan food production and shelter provision in the space they aim to settle, organizing and managing this space as a web of interconnected living systems within which they themselves live. The practice imaginary understands permaculture as a tool-box of scientific, empirical, and ethical elements. The scientific aspect aims at understanding the locus of the initiative by mobilizing conventional academic research from agro-ecology, chemistry, ecology and related fields - in order, for instance, to investigate the chemical nature of the soil and the interactions between different local species. The second element, 
its empirical or hermeneutic aspect, aims at developing ways to 'read' the territory to understand its 'patterns' - that is, the specific and hyper-localized identity of the territory, the species already implanted, their habits, the topography and micro-climate. For example, the permaculturist Sepp Holzer ${ }^{1}$ cultivates lemon trees in Alpine climatic conditions thanks to specific topographical niches within his domain - determined, for instance, by neighbouring cliffs - whose micro-climatic characteristics are reinforced by the installation of rocks and dense protective vegetation around the citrus trees. The third element - ethics, in the form of the core values of permaculture - guides the designers in combining the two previous elements to creatively and respectfully organize land use. For example, designers often 'divide' their territory in different zones, investing heavily in certain zones while dedicating others to spontaneous but limited gathering, so that some species' space needs (e.g. deer or wild pigs) can be better taken into account.

As an example, the Earthaven ecovillage is highly characteristic of the practice imaginary. Lockyer (2007) discusses its inhabitants' understanding of permaculture as "the belief $(. .$.$) that human life is inextricably embedded in the web of life which is the$ Earth, and that if we [the designers] choose patterns of land use and technologies appropriate $[\mathrm{ly}](\ldots)$ we will have the best chance of surviving over generations in a world we'd like to live in." Informants from Earthaven emphasized the fact that the basic setup of the community was based on concrete agricultural and land use organization, rather than on socio-political mobilization or philosophical speculation (see Table 1). ${ }^{2}$ Thus, in such practice-oriented systems, permaculture design is a template for creating sustainable

\footnotetext{
${ }^{1}$ http://www.krameterhof.at., retrieved on the 10/10/2017.

2 Earthhaven's website explains: “One of our first tasks was to create a permaculture-based site plan for developing our mountain forest property. We identified sacred sites; land to remain forested; areas for gardening, farming, and orchards; locations for ponds and hydro-power stations; locations for roads, paths, and common community buildings; and locations for residential neighborhoods. We agreed to build homes only on slopes and save flat bottom land for agriculture; retain as much water on the land as possible through roof water catchments, swales, and ponds; regenerate our soil with layers of organic biomass; protect our sacred sites; and not build on ridge tops. We build passive-solar heated buildings of natural Earth-friendly materials and generate our own off-grid power." (Earthaven home page, http://www.earthaven.org/ecological-living)
} 
and autonomous local agro-systems and communities that could inspire other people to engage in similar pursuits.

To illustrate this point, the company "Permaculture Design"3 outlines a methodology to build sustainable living places and systems that can result in "more autonomy (...) and more freedom"4, proposing training and consulting activities to "help people to build their (...) cultivated ecosystem" ${ }^{\prime 5}$. Similar to Earthaven, it emphasizes the goal $^{6}$ of transmitting and teaching in order to create "feeding, abundant, sustainable, resisting to shocks and crisis, and temporally stable landscapes so that future generations can enjoy this inheritance".

The basic understanding of permaculture in this imaginary is pragmatic, in that ecological and political goals are realized through material practices geared towards observable solutions. The "Permaculture Design" organization, for example, recommends following a "step by step" design "methodology" and, through specific training, locally adapting it. These practices involve a bricolage of shared know-how based on the specificities of the territory. We call this mode of collective organizing 'local-restricted' because the primary forum and unit of activity remains the local ecological 'workshop'. Community is built through the aggregation of autonomous local units sharing know-how, common interests and values; nevertheless, deep dependencies and interconnectedness do not characterize the macro-level community-building activity in the same way as the micro-level of the local ecological system itself. In other words, interconnectedness is highly valued locally - it is sought-after and organized by

\footnotetext{
${ }^{3}$ https://www.permaculturedesign.fr, retrieved on 13/02/2018 ${ }^{4}$ https://www.youtube.com/watch?v=kOcmh7oWGBA, retrieved on 13/02/2018.

${ }^{5}$ They further elaborate: "we help people to build their own house with natural materials, their own ecological heater system, to produce their own healthy food in a sustainable way, to set up their orchard, their pond (...), the access to their property, their ecological sanitation system" https://vimeo.com/129255701, retrieved on 13/02/2018.

${ }^{6}$ https://vimeo.com/129255701, retrieved on 13/02/2018.
} 
permaculture designers -yet it remains confined within the limits of the designed territory. Although different permaculture communities may generally recognize their interconnectedness or shared values, they remain strongly independent and do not take part in any common "macro-design"

The resulting systems of autonomous units within a larger community of interests and practices reflect a form of organization that we refer to as 'anarchistlibertarian' because it privileges local solutions, ad hoc designed systems, and the spirit of exploration and free association. Although such projects may have global utopian or systematic visions, their local focus may result in isolationist strategies. While some communities do take part in informal networks (for example, "Permaculture Worldwide Network" or "Brin de Paille" as common permaculture networks) where they can "share examples of permaculture design projects from their yards, gardens, farms, and broader communities" (Locker and Veteto, 2013: 12), this form of initiative focuses on the care they are able to provide within their own territories.

The global ecological threats foregrounded in the Anthropocene theory are here addressed through an imaginary embracing exemplarity, in which each local initiative provides workable solutions of sustainable food and shelter production that stand as possible inspirational models for others to emulate. The voluntary rapprochement of these anarcho-libertarian projects through informal networks, rather than being contradictory to their nature, can be seen as a way to respond to global-scale ecological threats through some kind of 'pollination' or 'invisible hand' logic. By focusing on individual practice, while taking part in, and sharing practices with, broader networks of like-minded communities, individual pursuits and refinement of practices may benefit other communities beyond one's locally-restricted area of activity. 
Permaculture as a Holistic Life Philosophy

Whereas permaculture initiatives tend to mobilize detailed knowledge about small-scale, locally-based production systems to create sustainable agricultural productions, they are often also described in much broader terms, as being couched in holistic life philosophies, or even in cosmic forms of spirituality. Since its outset, permaculture has been represented using elements of Aboriginal dreaming mythology and the ideas of cyclicality associated with this mythology (e.g. Mollison and Holmgren, 1978). Holmgren (2002) related permaculture to a form of spirituality, arguing that the precept of "caring the Earth" should be seen as both an "ethical restraint" and a "fear of motherly rejection and annihilation" (p. 4), thereby invoking the mythic figure of a sacred mother Gaïa, sometimes also called “our living all-powerful Mother” (p. 4).

Holmgren's spiritual agenda seems to reverberate with some permaculture communities. Permaculture has been a popular mode of production in alternative communities described as "new age" (e.g. Sutcliffe, 2003). One of the most well-known associations of this kind, the Findhorn community in Scotland, has used permaculture principles to promote sustainable waste disposal (Sutcliffe, 2003 .) as part of a way of life focused on personal spiritual transformation and the creation of a utopian community. The British Permaculture Association, in a similar vein, characterizes permaculture as "living lightly on the planet and making sure that we can sustain human activities for many generations to come, in harmony with nature" (Pickerell 2013: 183). Notions of harmony, spirituality and integration complement the minute details of permaculture practices, couching them in an ideological structure that legitimizes them in cosmic terms.

Although Anderson (2013: xiv) points out that "religion" in the permaculture context mainly implies a "reverent, respectful, caring, and responsible attitude toward the 
environment" rather than a particular sectarian movement, some permaculture communities have drawn explicitly on religious discourses, particularly those that emphasize cyclicality and rebirth. Birnbaum and Fox (2014: 197) found both the spiritual side and its diversity in the Lama Foundation, a permaculture community in New Mexico which began as a spiritual centre:

It has strong ties to Native American teachings through Taos Pueblo, and also incorporates elements of the Hanuman Temple, Sufi Ruhaniat, the Dervish Healing Order, the Church of Conscious Harmony, St. Benedict's Monastery, and other religious heritages.

The eclecticism characteristic of the spiritual rationale of permaculture, mixing multiple traditions in an overarching spirituality, seems consistent with an agricultural practice that emphasizes multiple species' interactions within an eclectic and interactive space.

Parsons (2013: 50) describes followers to this approach to permaculture as "bioregionalists" who constitute "a spiritually motivated, back-to-the-land" community, placing a simultaneous emphasis on transcendentalism and the down-to-earth, an imagined unity between the whole and its parts. Explaining permaculture initiatives as a new form of transcendentalism, he adds that "they frequently look to the ecological wisdom, the values, the land ethic of the American Indians, living in Rousseau-like harmony with nature [sic] before the arrival of "the invaders", as a model".

Regardless of the empirical validity of the description of indigenous practices upon which such permaculture initiatives lean, the vision of a perfect harmony within 'nature,' taken allegorically, may assist in problematizing dominant modes of thinking the relation between humans and the environment. By opening up conceptual space for new utopias, it complements the more "down to earth" focus of the practical imaginary. 
In another example of the holistic life philosophy imaginary, members of the project "Grand Chêne" describe permaculture as a "concept which generates an attitude toward Life" and the conscience "of the importance of a harmonious relationship with (...) the Earth" that "naturally brings us to consider the place of individuals in their environment". In order to further ground this "conscience", they developed what they call "life exercises", mixing meditation activities with far-Eastern practices such as Shintaïdo.

Such approaches demonstrate the underlying idealism of the holistic life philosophy imaginary, with implications for its critical potential. Focusing on unity or harmony does not in itself foreclose on possibilities for social and political struggle. However, presupposing harmony as already given (or as part of an idealized past), rather than as the outcome of prolonged struggle, may de-claw the political potential of such movements (Mannheim, 1936; Vogt, 2016). The presumption of unity as "already here", as Mannheim (1936) argues, can signal the conversion from "utopia" to "ideology", and motivate potentially transformative movements to stress acceptance over radical change.

On the other hand, such imaginaries could certainly be used as resources to envision what kind of relationships we could sustain with other-than-human living entities, and, more specifically, what it could mean to develop harmonious or spiritual relationships with such entities. The ecofeminists Chris Cuomo (1998) and Val Plumwood (2002), for instance, proposed useful theoretical paths by arguing for an ethos of "flourishing" to guide human relations with other-than-human entities. Cuomo advances the idea of "dynamic charm", to emphasize the value of the immanent tendencies and affective forces of individuals towards aggregates of living entities (Lorimer, 2012). "Dynamic charm" as a sense of "response-ability" (Haraway, 2008) can

${ }^{7}$ https://le-grandchene.weebly.com/ 
act as a relational force that supports adaptation to environmental change while drawing multi-species others into relationships (Lorimer, 2012). Similar claims are found in the concepts of "careful" ecologism (Hinchliffe, 2008) and "friendship" relationships with other entities (Bingham, 2006). All of these conceptions rely on re-imagined concepts of connection, relation and harmony.

As a transformative organizational model, emphasizing the holistic and the transcendental speaks to immediate concerns that critical scholars may have regarding permaculture initiatives - their focus on small-scale organizing and the ensuing possible withdrawal from macro-level socio-political transformation. The notion of a transformed human in harmony with an integral nature goes beyond practices as 'quick-fixes,' stressing the need for the transformation of the human in its positioning with respect to other living entities. Given that permaculture "provides principles and tools for working with the social, economic, ecological, and cultural pillars of development in an integrated, holistic, and synergistic way" (Pyhälä, 2013: 200), it is consistent with a life philosophy that integrates individuals, societies, and nature into a seamless whole, and in this way responds directly to the problematization of the human within the concept of the Anthropocene. Furthermore, the moral stance this position represents, linked to the virtues of unity and harmony, provides a normative wedge that may have critical potential, and that can mobilize commitment.

Permaculture as an Intersectional Movement

A third overarching imaginary of permaculture involves its framing as a socialecological movement that integrates, and contributes to, other social justice initiatives, while self-consciously engaging in a multi-species conception of politics (Haraway, 2015). By "intersectional", we refer to the conjunction of responses to different sources 
of injustice (Crenshaw, 1991) which may be articulated together across species boundaries (Haraway, 2015; Puar, 2012).

To illustrate, Rosa (2015) demonstrated how the Brazilian permaculture initiative Kilombo Permangola ${ }^{8}$ intermeshes an emphasis on agricultural sustainability with, among others, class- and race-based social justice movements. Another example can be found in a number of ecovillages in Colombia, described by Burke and Arjona (2013: 235) as mechanisms for creating "alternative political ecologies" that question capitalism as a mode of living and a form of subjectivity. Such initiatives embrace agricultural practices in the wider context of cross-cutting political transformations linked with other justice movements.

Pickerell's (2013) discussion of Low Impact Developments (LIDs) in the U.K. is illustrative of the cross-cutting possibilities of such intersections. The LIDs were designed to be autonomous in their water, waste and energy needs, and to meet the majority of food needs from local sources. Stress was laid on the principles of sharing of functionally important goods between people and across species. Regarded not simply as a cultivation practice but as a "radical approach to housing, livelihoods and everyday living" (Pickerell, 2013: 181), the LIDs were a bottom-up response to economic and ecological crisis, seeking alternative housing and economic possibilities outside the capitalist system.

Similarly, Dawson's (2013) study of ecovillages links ecological sustainability with social justice issues, and stresses integration across the global North and South. Using the example of healthcare, he illustrates how wider social issues are addressed by such communities:

${ }^{8}$ http://www.kilombotenonde.com/ 
[R]adical experiments in holistic health and education proliferated. The Farm in Tennessee went so far as to set up its own primary health care system with laboratories, dispensary, infirmaries, outpatient care, ambulance service, neonatal ICU, holistic midwifery center, and training clinics for "barefoot doctors". (Dawson 2013: 221)

Kilombo Permangola in Brazil, the LIDs in the U.K. and the ecovillages Dawson discusses are self-consciously political, explicit about their intentions to create alternative social orders that include consideration both of nature and of excluded social groups. Such initiatives resemble work within organizational scholarship on alternative organizing, such as Land and King's (2014) study of a voluntary sector group that mixed permaculture with radical politics, providing:

[A] meeting space for local activists, a social change library, newsletter, permaculture garden, a veg box scheme and a variety of educational courses. Rooted in DIY, anarchist activism they were also home for [sic] a wide range of alternative, radical social groups- environmentalist, hunt-sabs, anarchists and community activists. The centre provided a community for anyone feeling excluded from the rapidly globalizing, homogeneous culture dominant in wider society (WE Annual Report 2012). (Land and King, 2014: 933)

The idea that such groups provide "a community for anyone feeling excluded" undergirds the intersectional nature of such groups as drawing equivalences across different modes of social injustice, and thereby building cross-cutting social movements that have counter-hegemonic potential (Laclau, 1996).

The social movement imaginary is local in orientation but seeks, as a fundamental part of its operation, to cut across local systems and to build wider politicized allegiances (what we termed in Table 1 'local-solidaristic'). Thus, permaculture initiatives motivated by such an imaginary are more likely to problematize pillars of the establishment such as individual property rights, and are more focused on solidaristic networks than on efficient land-productivity use, although the two may be complementary. This implies, for example, that when in conflict, locally efficient allocations of resources such as individual 
control of a plot might be less valued than communal decision-making and fair distribution of land yields.

In terms of the social-transformative possibilities of such an imaginary, its main advantages stem from the emphasis on social solidarity and inclusion, and the selfconsciously political aspects of the practices it motivates. By dialoguing across different social movements, new progressive political imaginaries may be formulated in ways that are less likely to privilege parochial interests and more likely to emphasize common ground. Permaculture thus mobilized as a tool to achieve justice would take the role of a social counter-power against an established system. To illustrate, Kilombo Permangola emphasizes a politically charged identity based on the strong symbolism of the "quilombos" - forest refuges historically established by escaped slaves that would shelter persecuted groups. They link permaculture to the tradition of Capoeira Angola - a ritualized fight-dance practice born clandestinely, which served to empower enslaved Afro-Brazilian groups and is traditionally associated with counter-cultural movements in Brazil (Assunção, 2005).

At the same time, the permaculture imaginary focused on intersectional social justice raises several critical questions. While perhaps less likely to be appropriated for capitalistic purposes because of their avowedly political orientation, such initiatives may have difficulty finding common interest between groups without resorting to abstract “empty signifiers" (Laclau, 1996). Moreover, the political-transformative ambitions of such groups may be limited by the fact that they lack both the institutional power base needed to challenge the establishment, and the formal organizational and regulatory capacity to pose serious political alternatives. Relatedly, although more 'macro' than initiatives operating according to the practice imaginary, one might question whether 
such initiatives are able to scale up to become significant actors at a national or global governance level.

<insert Table 1 here>

\section{Summary: Re-imagining the Anthropocene}

The permaculture imaginaries we have considered offer alternative visions of human integration across local, global, and political environments. The first imaginary of permaculture as practice focused on integrating species across organized levels or zones (Mollison and Holmgren, 1978). Each system is organized as a self-contained whole. The result is an accumulation of permaculture communities with their idiosyncratic practices, each optimized for a given locality, but with no over-arching structure other than the commitment to permaculture as a method. Rather than deny the anthropogenic impacts of agro-systems, this imaginary manages those impacts in order to optimize sustainability. Interspecies boundaries are exploited to create a common, shared space of co-habitation. Boundaries between species are also conceptualized as contact points, supporting interactions, exchanges and creative co-habitation (Mollison, 1988), creating the conditions for "complex life assemblies and energy translators" (Mollison, 1988:74). The imaginary of a porous, integrative boundary helps to rethink non-human integration into humanized spaces, a key concern in the Anthropocene.

The 'holistic' life philosophy imaginary, on the other hand, focuses on dissolving the notion of boundaries to establish unity. While similarly motivated by a drive toward integration, the integration in question here is that of human concerns with the global holistic Earth-system. Local permaculture communities are seen as part of an integrated, holistic "network" (e.g. Dawson, 2013) including the Earth itself, and although local practices remain idiosyncratic due to particular input/output endowments, they are all subsumed under a holistic vision. The spiritual imaginaries of permaculture 
envisage the possibility of human integration with 'Gaïa' through an attitude of mutuality and relationality, inviting humans to enter a caring relation with their environments.

Neither locally bounded nor holistic, the intersectional imaginary sees permaculture movements as integrated within diverse, cross-cutting social justice concerns (e.g. Fraser, 2014; Pyhälä, 2013). Boundaries (species, class, gender, ethnic) are affirmed as sources of social injustice and transformed through building "chains of equivalence" connecting subjects sharing common grievances (Laclau, 1996). Boundaries are highlighted to emphasize, critique and question the distribution of power and privileges among beings, and deployed as symbolic protective fences. In the global context of permaculture imaginaries, such boundaries could be also thought of as a way to protect those non-human entities whose endangered status would require a specific mobilization or struggle.

Although these imaginaries are distinct enough that they could be viewed as “contested imaginaries" (Levy and Spicer, 2013), they coexist in practice, sharing the aim of establishing interaction and integration between human beings and their planetary companions. This integration is built through the construction of shared spaces, practices and interests, with a community of stakeholders anchored at different organizational levels (cf. Laine, 2010). Permaculture organizing principles strive to create spaces where each species can both respond to the environment in its own characteristic way and also support the forms of life of inter-species 'others'.

Permaculture imaginaries, then, are fundamentally about the organizing of 'collectives' across human and non-human entities. Imagining relationality across these different group (Yusoff and Gabrys, 2011), permaculture designs the action of "collection" - the gathering, harvesting and assesmblage of diverse elements (Descola, 
2017) into systems that allow heterogeneous beings to cohabit and support each other. As "utopian" imaginings (Anderson, 2013), permaculture relies on small, experimental and localized communities. As Anderson (2013) argues of eco-political revolutionary traditions, such utopian imaginaries run counter to mass-movement based ecological variants: "the former runs the risk of gradualism. The latter runs the risk of transforming the world only to find out too late that the plan was badly flawed" (Anderson, 2013: xiii). Permaculture is then characterized as a utopian, experimentalist variety of microrevolution. Regardless of their ultimate efficacy, such change initiatives are useful precisely because their experimentalism gives rise to a heterogeneous proliferation of possibilities, creating an "archive" of utopian possibilities that provide a resource for alternative political organizing (Zanoni et al., 2017).

Permaculture thus responds to the ecological considerations foregrounded by the idea of the Anthropocene by: i) rejecting boundaries as a symbolic place of exclusion, taking into consideration the stakes of other entities and their interests to exist as legitimate members of a multi-species community; and ii) acquiescing to the principle of limiting human action in order to respect non-humans and the Earth. The recognition of humans' role in the Earth-system is at the same time a recognition of responsibility towards non-humans. In this sense, the Anthropocene anthropomorphizes the environment, to avoid its anthropocentrism (cf. Avelar, 2013). Permaculture imagines a vast community of communities in which humans are agents, but which also contain interests beyond the human. By learning to interpret the dynamics of interaction within these communities, it seeks to satisfy the needs of human collectives without jeopardizing these broader interconnections. 


\section{Discussion}

The current paper began with the question of how the Anthropocene's repositioning of the relation of humans to nature informs critical studies of organizations, with a view towards establishing organizational responses to this re-positioning (cf. Gosling and Case, 2013; Laine, 2010). Focusing on permaculture as a paradigmatic organizing movement, we have critically examined how different imaginaries around permaculture create diverse practical, socio-political and ecological imaginaries that can have important ramifications on the organizing of Earth-inhabiting processes in the face of the Anthropocene. Rather than advocate for or critique permaculture as such, we have laid out some of the constitutive choices permaculture initiatives make, together with their implications. Ultimately, we believe that such imaginaries are not limited to permaculture, but hold lessons for critical and alternative organizations more generally.

Specifically, by focusing on permaculture as a source of imaginaries, we contribute to understanding how imaginaries and practices combine in diverse ways, and how these combinations direct the social and political possibilities of alternative organizations. Within organizational scholarship, imaginaries have been noted as a way of promoting alternative or critical management perspectives (Zanoni et al., 2017) and as establishing the relation of social and political ideas with material forms (Medeiros et al., 2017). Regarding the natural environment, moreover, Wright et al. (2013: 650) have noted that understanding imaginaries is essential for seeing ecological crisis as a social and political phenomenon, rather than allowing it to be naturalized as "the way things are”. Organizing around the Anthropocene requires viewing human and natural destinies as intertwined, and "dreaming" new ways of being together with the natural environment (Gosling and Case, 2013). 
We bring to this emerging discussion additional support though two insights that are complementary to the above literature. First, although imaginaries have been linked to social practice (Castoriadis, 1987 /1975), the concrete practices of land, space and species organizing implied by permaculture further this focus on the material embeddedness of imaginaries. Second, the diverse imaginaries associated with permaculture give rise not to one but to an array of organizing alternatives, each with different ramifications for the relations of humans with each other, with other species and with their natural environments. This second observation implies that the political and ideological ramifications of permaculture are likely to depend on their constitutive imaginaries, which, as we have demonstrated, can vary from anarcho-libertarian, to transcendental, quasi-religious, and/or social activist movements.

We contribute to thinking about organizing in the Anthropocene in three interrelated ways. First, our discussion fills a gap in theorizing social-ecological organizing movements, of which permaculture initiatives are a prime example. Second, it contributes to thinking more generally about organizational responses to the Anthropocene, discussing changing human-environment relations and theoretically illustrating the stakes of these relations through paradigmatic cases. Third, it contributes to critical management studies perspectives by showing the heterogeneity of such movements as based in their practices, philosophy and politics.

Permaculture Movements from an Organizational Perspective

With some exceptions (e.g. Land and King, 2014; Mannen et al., 2012), little research on permaculture exists within organizational research, or within the social sciences more generally. As Veteto and Lockyer (2013: 98) note, permaculture "has been largely ignored" by academia, partially due to the difficulties raised by the 
interdisciplinarity required for a serious study of permaculture. They cite Mollison's frustration at this obstacle, for instance: "the professional community was outraged, because we were combining architecture with biology, agriculture with forestry, and forestry with animal husbandry, so that almost everybody who considered themselves to be a specialist felt a bit offended" (Mollison 1991: preface). More pertinent to our critical assessment was Holmgren's (2002: xxii) position on utopian agriculture, also cited in Veteto and Lockyer (2013: 98): “many who are involved in large-scale agriculture and land use policy saw it as theoretical, utopian and impractical because it was difficult to apply within the prevailing social, market and policy environment." Thus, the question of disciplinarity and professional acceptance was itself embedded in assumptions about the viability of certain models of production within the prevailing political economy, and responses that were felt to be to 'utopian' were not considered worthy of attention.

Within organization studies, however, interest in utopian imaginaries is emerging in the form of studies of alternative organizational forms and organizing activities (Gosling and Case, 2013; Land and King, 2014; Parker et al., 2007; Zanoni et al., 2017). Looking at attempts to realize 'utopian' organization, or "real utopias" (Wright, 2013), holds important lessons for the organizing and building of new ecological imaginaries (Gosling and Case, 2013; Perey, 2016). While emergent organizational research examines how corporations discursively turn critical climate issues to their benefit through re-imagining crisis as normal business (Nyberg and Wright, 2016), this may be complemented by examinations of how alternative organizations determine what may or may not be possible, and in the process illustrate principles that may prove crucial for future organizing practices. 
Empirical studies following particular permaculture initiatives as they unfold, tracing the evolving relations between humans, land, and other species, are lacking, and constitute an important gap in our understanding of organizational responses to the Anthropocene (Alcaraz et al., 2016; Heikkurinen et al., 2015). The current study does not engage in this kind of empirical effort; however, we prepare the terrain for such research by broadly considering the diverse imaginaries involved in such initiatives. Each of these imaginaries produces possible horizons for organizing, while obscuring others; thus, examining the imaginaries of nascent organizing movements is a key initial step that needs to be taken before our understanding of their political possibilities and their possible shortcomings can be deepened through empirical work.

Organizing as Reimagining Human-Environment Relationships

An increasing amount of organizational research examines discursive and political struggles around the meaning of environmental events (e.g. Hoffman and Jennings, 2011; Levy and Egan, 2003; Nyberg and Wright, 2016; Wright and Nyberg, 2012). The current study complements, but distinguishes itself from, this literature in two important ways. First, by moving from the corporate construction of environmental events to the construction by alternative organizations of the role of humans in the natural environment, we foreground actors in this discursive field that have been given very little attention by organizational scholars (e.g. Land \& King, 2014; Mannen et al., 2012). Second, by turning from the issue of discursive struggles undertaken by corporations seeking external legitimacy, we consider diverse alternative imaginaries mobilized by actors within the permaculture movement attempting to respond, and adapt, to environmental crisis. Although permaculture has been recognized as proposing an alternative future for inhabiting the Earth (e.g. Uphoff 2002; Ergas and Clements 2015; 
Hataway, 2015), the notion of alternative imaginaries of permaculture as an organizational phenomenon has not been discussed. The stakes of environmental discourses for permaculture actors are quite distinct from those of corporate actors, because for the former, their basic raison d'être depends on their position in this discourse, while corporate actors may be more likely to deploy environmental discourses as one among an array of organizational priorities. Without a re-thinking of humans' role in nature, permaculture is not possible; thus, this field is particularly apt for exploring the kinds of environmental imaginaries possible in the context of the Anthropocene.

Critical Perspective on Utopian and Ecological Organizing

Finally, given our positioning of this work within CMS, our discussion aims to contribute to understanding the critical and transformative possibilities of alternative environmental movements, an area within CMS that has received relatively little attention. Whereas, for example, critical work around the ambivalent conceptions of holistic and "well-being" movements, such as humanistic management or spiritual management, is prolific (cf. Bell and Taylor, 2003; Islam, Holm and Karjalainen, 2017), much less has been written about the stakes of organizing around holistic human-nature relations. Although evaluating such movements requires close empirical work that is beyond the scope of this paper, our intention is to understand organizational responses to the Anthropocene as ambivalent in the same way as other ostensibly emancipatory movements (e.g. Barros, 2010), with the associated dangers of appropriation, in-fighting, and mission drift, but also with the potential to drive real change through imagining alternative futures. Our critical appraisal of permaculture is meant to shed light on such potentials while, at the same time, problematizing many of the premises associated with permaculture imaginaries. 


\section{Directions for Future Research}

Despite the above contributions, the current study has limitations and is meant to open the ground for future research about organizational possibilities in the Anthropocene. First, as mentioned above, empirical work should map out the varieties of "on-the-ground" transformative movements and their successes and failures. Such work should look both within movements, to understand how they develop understandings of, and practices toward, the natural environment and its inhabitants, and across movements, to understand their empirical diversity and comparative impacts. As we have noted, the three imaginaries described above are heuristic in nature and meant to dispel the notion that permaculture organizing is a unified and easily characterizable field. We reiterate that a given initiative is likely to contain elements of all three imaginaries. Thus the heterogeneity of permaculture initiatives is likely to be much greater than this tripartite distinction of imaginaries implies, as empirical cases fall at different places along the different continua. By looking at these in practice, the schematic shown in this paper can be further developed or modified.

Second, research should compare social/ecological oriented organizations with profit-based corporations and other organizational types (e.g. Nyberg and Wright, 2016). Though both are likely to be driven by legitimacy concerns, they are likely to differ in how they imagine ecological threats. In the current study, permaculture served an illustrative purpose, as permaculture actors are likely to be on the cutting edge of reimagining human-nature relations. Traditional organizations may be more likely to carry over more baggage from existing institutional orders; however, the extent to which more radical discourses may infiltrate such organizations is not yet known, and the processes by which such infiltration occurs is an important area for research. 
Finally, our discussion suggests that organizational responses to the Anthropocene are likely to involve scale issues, either retreating to hyper-local solutions or, conversely, demanding Earth-level or universalizing imaginaries. A central question, then, becomes that of reconciling the local focus of much environmental discourse with the scale needed for mass social change and preparedness for the Anthropocene. Each of the imaginaries described above, from small scale DIY projects to cosmic visions of holistic unity, deals in its own way with this issue of scale. Future research should discuss how the scale of organizing is likely to be impacted as actors attempt to respond to environmental challenges.

\section{Conclusion}

Looking back to Anderson's (2013) comparison of the experimentalism of utopian, small-scale communities and the steamroller effect of mass-movement revolution, we note that our study has focused on the former, partially because it is more amenable to examining heterogeneity, and partially because the mass movement has yet to materialize with respect to the environmental concerns relating to the Anthropocene. Anderson argues that both types of movement are needed as "time is short". Mass mobilization around the Anthropocene seems out of sight, with continual breakdown at the level of international governance and the ongoing discursive struggle over climate politics (Schüßler et al., 2014). Permaculture, with its utopian leanings and local imaginaries, takes up the project on the micro side, with all the limitations, instrumentalism, and coordination problems this implies. However, by creating minilaboratories of agricultural, as well as philosophical and social experimentation, permaculture movements provide material for understanding organizing processes that, if they are to ever take hold in the public consciousness, will be crucial for the future of 
humanity. These movements do not escape the paradoxes and dilemmas of their time; they recycle them, wagering that with enough fiddling, some loosening of the current social and ecological bind is possible.

\section{References}

Alcaraz, J. M., Sugars, K., Nicolopoulou, K. and Tirado, F. (2016) 'Cosmopolitanism or Globalization: The Anthropocene Turn', Society and Business Review 11(3): 313332.

Anderson, E. N. (2013) 'Introduction', in J. Lockyer and J. R. Veteto (eds) Environmental Anthropology Engaging Ecotopia: Bioregionalism, Permaculture and Ecovillages, pp. xi-xviii. NY: Berghahn.

Appadurai, A. (1990) 'Disjuncture and Difference in the Global Cultural Economy', Public Culture, 2(2): 1-24.

Appadurai, A. (2016) Banking on Words: The Failure of Language in the Age of Derivative Finance. Chicago: University of Chicago Press.

Assunção, M. R. (2005) Capoeira: The History of an Afro-Brazilian Martial Art. London: Routledge.

Avelar, I. (2013) 'Amerindian Perspectivsm and non-Human Rights', Alternativas 1: 121.

Barnosky, A.D., Matzke, N., Tomiya, S., Wogan, G. O. U, Swartz, B., Quental, T. B., Marshall C., et al. (2011) 'Has the Earth's sixth Mass Extinction already arrived?', Nature 471: 51-57.

Barros, M. (2010) 'Emancipatory management: The contradiction between practice and discourse', Journal of Management Inquiry, 19(2): 166-184.

Bell, E. and Taylor, S. (2003) 'The Elevation of Work: Pastoral Power and the New Age Work Ethic', Organization 10(2): 329-349.

Bingham, N. (2006) 'Bees, Butterflies, and Bacteria: Biotechnology and the Politics of Nonhuman Friendship', Environment and Planning A 38: 483-498.

Birnbaum, J. and Fox, L. (2014) Sustainable Revolution: Permaculture in Ecovillages, Urban Farms, and Communities Worldwide. Berkeley: North Atlantic Books.

Burke, B. and Arjona, B. (2013) 'Experiments with Alternative Political Ecologies: Examining the Construction of Ecovillages and Ecovillagers in Colombia' in J. Lockyer and J. R. Veteto (eds) Environmental Anthropology Engaging Ecotopia: Bioregionalism, Permaculture and Ecovillages, pp. 235-250. NY: Berghahn.

Canavan, G. and Robinson, K. S. (2014) 'Introduction: If this goes on', In G. Canavan and K. S. Robinson (eds). Green Planets: Ecology and Science Fiction. Middletown, CT: Wesleyan University Press.

Castoriadis, C. ([1975] 1987) The Imaginary Institution of Society. Cambridge: The MIT Press.

Chakrabarty, D. (2009) 'The Climate of History: Four Theses', Critical Inquiry 35: 197222.

Chakrabarty, D. (2014) 'Climate and Capital: On Conjoined Histories', Critical Inquiry 41(1): 1-23. 
Crenshaw, K. (1991) 'Mapping the Margins: Intersectionality, Identity Politics, and Violence against Women of Color', Stanford Law Review 43(6): 1241-1299.

Crutzen, P. J. (2002) 'Geology of Mankind: The Anthropocene', Nature 415(3): 23.

Cuomo, C. J. (1998) Feminism and Ecological Communities: An Ethic of Flourishing. London: Routledge.

Dawson, J. (2013) 'From Islands to Networks: The History and Future of the Ecovillage Movement', in J. Lockyer and J. R. Veteto (eds) Environmental Anthropology Engaging Ecotopia: Bioregionalism, Permaculture and Ecovillages, pp. 217234. NY: Berghahn.

Descola, P. (2005) Par-delà Nature et Culture. Paris: Gallimard.

Descola, P. (2017) 'Cosmopolitics of Territoriality', Course in Collège de France, retrieved from https://www.college-de-france.fr/site/philippe-descola/course2017-02-01-14h00.htm in February 2017

Dillon, M. G., and Lobo-Guerrero, L. (2009) 'The biopolitical imaginary of speciesbeing', Theory, Culture \& Society 26(1), 1-23.

Escobar, A. (1999) 'After nature: Steps to an antiessentialist political ecology', Current Anthropology 40(1), 1-30.

Federau, A. (2017) Pour une Philosophie de l'Anthropocène. Paris : Presses Universitaires de France.

Ferguson, R. S. and Lovell, S. T. (2014) 'Permaculture for Agroecology: Design, Movement, Practice, and Worldview. A Review', Agronomy for Sustainable Development 34(2): 251-274.

Foster J. B. (1999) 'Marx's Theory of Metabolic Rift: Classical Foundations of

Environmental Sociology', American Journal of Sociology 105(2): 366-405.

Foster, J. B. (2000) Marx's Ecology: Materialism and Nature, New York: monthly Review Press.

Fraser, N. (2014) 'Behind Marx's Hidden Abode: For an Expanded Conception of Capitalism', New Left Review 86: 55-72.

Fujimura, J. H. (2003) 'Future Imaginaries: Genome Scientists as Sociocultural Entrepreneurs'. In ed. Goodman, A. H. Genetic Nature/Culture: Anthropology and Science beyond the Two-Culture Divide, 176-199, Berkeley: University of California Press.

Gaonkar, D. P. (2002) 'Toward New Imaginaries: An Introduction', Public Culture 14(1): $1-19$.

Godfray, H. C. J., Crute R. I., Haddad, L., Lawrence, D., Muir J. F., Nisbett, N., Pretty J. et al. (2010) 'The Future of the Global Food System', Philosophical Transactions of the Royal Society B 365: 2769-2777.

Gosling, J. and Case, P. (2013) 'Social Dreaming and Ecocentric Ethics: Sources of NonRational Insight in the Face of Climate Change Catastrophe', Organization 20(5): 705-21.

Haraway, D. (1997) Modest_Witness@Second_Millenium.FemaleMan_Meets_Onco Mouse: Feminism and Technoscience. London: Routledge.

Haraway, D. (2008) When Species Meet. Minneapolis, MN: University of Minnesota Press.

Haraway, D. (2015) 'Anthropocene, Capitalocene, Plantationocene, Chthulucene: Making Kin', Environmental Humanities 6: 159-165.

Haenn, N. and Wilk, R. R. (eds. 2006) 'The Environment in Anthropology: A Reader' in. Ecology, Culture, and Sustainable Living. New York: NYU Press. 
Heikkurinen, P., Rinkinen, J., Järvensivu, T., Wile, K. and Ruuska, T. (2015) 'Organising in the Anthropocene: An Ontological Outline for Ecocentric Theorizing', Journal of Cleaner Production 113: 705-714.

Hinchliffe, S. (2008) 'Reconstituting Nature Conservation: Towards a Careful Political Ecology', Geoforum 39: 88-97.

Hoffman, A. J. and Jennings, P. (2011) 'The BP Oil Spill as a Cultural Anomaly? Institutional Context, Conflict, and Change', Journal of Management Inquiry 20(2): 100-12.

Holmgren, D. (2002) Permaculture: Principles and Pathways beyond Sustainability. East Meon: Permanent Publication Editions.

Howden, S. M., Soussanat, J. F., Tubiello, F. N., Chhetri, N., Dunlop, M. and Meinke, H. (2007) 'Adapting Agriculture to Climate Change', Proceeding of the National Academy of Sciences 104(50): 19691-19696.

Islam, G., Holm, M. and Karjalainen, M. (2017) 'Signs of the Times: Workplace Mindfulness and the Oppositions of Management', Organization, onlinefirst.

Jessop, B. (2010) 'Cultural political economy and critical policy studies', Critical Policy Studies 3: 336-356.

Kallis, G. (2011) 'In Defense of Degrowth', Ecological Economics 70: 873-880.

Kohl, B. and Farthing, L. (2012) 'Material constraints to popular imaginaries: the extractive economy and resource nationalism in Bolivia', Political Geography 31(4): 225-235.

Laclau, E. (1996) Emancipation(s). London: Verso.

Laine, M. (2010) 'The Nature of Nature as a Stakeholder', Journal of Business Ethics 96: 73-78.

Land, C. and King, D. (2014) 'Organizing Otherwise: Translating Anarchism in a Voluntary Sector Organization', Ephemera 14(4): 923-950.

Larrère, C. and Larrère, R. (2009) Du Bon Usage de la Nature. Pour une Philosophie de l'Environnement. Paris: Flammarion.

Leclère, D., Havlík, P., Fuss, S., Schmidm E., Mosnier, A., Walsh, B. et al. (2014) 'Climate Change Induced Transformations of Agricultural Systems: Insights from a Global Model', Environmental Research Letters 9(12): 1-14.

Levy, D. L. and Egan, D. (2003) 'A Neo-Gramscian Approach to Corporate Political Strategy: Conflict and Accommodation in the Climate Change Negotiations', Journal of Management Studies 40: 803-830.

Levy, D. and Spicer, A. (2013) 'Contested Imaginaries and the Cultural Political Economy of Climate Change', Organization 20(5): 659-678.

Lockyer, J. (2007) Sustainability and Utopianism: An Ethnography of Cultural Critique in Contemporary Intentional Communities (unpublished $\mathrm{PhD}$ dissertation, University of Georgia).

Lockyer, J. and Veteto, J. R. (eds) (2013) Environmental Anthropology Engaging Ecotopia: Bioregionalism, Permaculture and Ecovillages. New York: Berghahn.

Lorimer, J. (2012) 'Multinatural Geographies for the Anthropocene', Progress in Human Geography 36(5) 593-612.

Malm, A. and Hornborg, A. (2014) 'The Geology of Mankind? A Critique of the Anthropocene Narrative', The Anthropocene Review 1(1): 62-69.

Mannen, D., Hinton, S., Kuijper, T. and Porter, T. (2012) 'Sustainable Organizing: A Multiparadigm Perspective of Organizational Development and Permaculture Gardening', Journal of Leadership and Organizational Studies 19(3): 355-368. 
Mannheim K. (1936) Ideology and Utopia: An Introduction to the Sociology of Knowledge. London: Routledge and Kegan Paul.

Martinez-Alier, J., Anguelovski, I., Bond, P., Del Bene, D., Demaria, F., Gerber, J.-F. et al. (2014). Between activism and science: Grassroots concepts for sustainability coined by environmental justice organizations, Journal of Political Ecology 21: $20-60$.

McIntyre, B. D., Herren, H. R., Wakhungu, J. and Watson, R. T. (eds) (2009) 'Agriculture at a Crossroads International Assessment of Agricultural Knowledge', Science and Technology for Development (IAASTD): Global Report, Washington DC: IslandPress.

Medeiros, F., Islam G. and Toraldo, M (2017) 'Multimodal Imaginaries and the "Big Worm": Materialities, Artefacts and Analogies in São Paulo's Urban Renovation', Research in the Sociology of Organizations, 54A: 27-62.

Milkoreit, M. (2017) 'Imaginary Politics: Climate Change and Making the Future', Elementa: Science of the Anthropocene, 5: 62.

Mollison, B. (1979) Permaculture Two: Practical Design for Town and Country in Permanent Agriculture. Sisters Creek: Tagari Publications.

Mollison, B. (1988) Permaculture: A Designer's Manual. Sisters Creek: Tagari Publications.

Mollison, B. (1994) Introduction to Permaculture. Sisters Creek: Tagari Publications.

Mollison, B. and Holmgren, D. (1978) Permaculture One: A Perennial Agricultural System for Human Settlements. Sisters Creek: Tagari Publications.

Moore, J.W. (ed.) (2016) Anthropocene or Capitalocene? Nature, History, and the Crisis of Capitalism. Oakland: PM Press.

Naess, A. (1989) Ecology, Community, and Lifestyle. Cambridge: Cambridge University Press.

Nyberg, D. and Wright, C. (2016) 'Performative and Political: Corporate Constructions of Climate Change Risk', Organization 23(5): 617-638.

Palsson G., Szerszynski, B., Sörlin, S., Mark, J., Avril, B., Crumley, C. et al. (2013) 'Reconceptualizing the Anthropos in the Anthropocene: Integrating the Social Sciences and Humanities in Global Environmental Change Research', Environmental Science and Policy 28: 3-13.

Pant, L. P. (2016) 'Paradox of Mainstreaming Agroecology for Regional and Rural Food Security in Developing Countries', Technological Forecasting and Social Change 111: 305-316.

Parker, M., Fournier, V. and Reedy, P. (2007) The Dictionary of Alternatives: Utopianism and Organization. New York: Zed books.

Parsons, J. (2013) 'On Bioregionalism and Watershed Consciousness' in J. Lockyer and J. R. Veteto (eds) Environmental Anthropology Engaging Ecotopia: Bioregionalism, Permaculture and Ecovillages, pp. 49-57. NY: Berghahn.

Perey, R. (2016) Ecological Imaginaries Reframing Organisation. Copenhagen: Copenhagen Business School Press.

Pickerill, J. (2013) 'Permaculture in Practice: Low Impact Development in Britain' in J. Lockyer and J. R. Veteto (eds) Environmental Anthropology Engaging Ecotopia: Bioregionalism, Permaculture and Ecovillages, pp. 180-194. NY: Berghahn.

Plumwood, V. (2002) Environmental Culture: The Ecological Crisis of Reason. London: Routledge. 
Polanyi, K. (2001/1944) The Great Transformation. The Political and Economic Origins of our Time. Boston: Beacon Press.

Puar, J. (2012) "II Would Rather Be a Cyborg than a Goddess" Becoming-intersectional in Assemblage Theory', philoSOPHIA 2(1): 49-66.

Pyhälä, A. (2013) 'In Search of Global Sustainability and Justice: How Permaculture Can Contribute to Development Policy' in J. Lockyer and J. R. Veteto (eds) Environmental Anthropology Engaging Ecotopia: Bioregionalism, Permaculture and Ecovillages, pp.195-212. NY: Berghahn.

Rickards, L. and Howden, S. M. (2012) 'Transformational Adaptation: Agriculture and Climate Change', Crop and Pasture Science 63: 240-250.

Rosa, C. F. (2015) Brazilian Bodies and their Choreographies of Identification. NY: Palgrave.

Schechner, R. (2015) Performed Imaginaries. New York: Routledge

Schlosberg, D. (2016) 'Environmental Management in the Anthropocene', in Gabrielson, T., Hall, C., Meyer J. M., and Schlosberg D. (eds), The Oxford Handbook of Environmental Political Theory. Oxford: Oxford University press.

Schüßler, E., Rüling, C. and Wittneben, B. (2014) 'On Melting summits: The Limitations of Field-Configuring Events as Catalysts of Change in Transnational Climate Policy', Academy of Management Journal (57): 140-171.

Serres, M. (2001) Hominescence. Paris: Le Pommier.

Steffen, W., Crutzen, P. J. and McNeill, J. R. (2007) 'The Anthropocene: Are Humans Now Overwhelming the Great Forces of Nature?', AMBIO: A journal of the Human Environment (36)8: 614-621.

Steffen, W., Grinevald, J., Crutzen, P. and McNeill, J. (2011) 'The Anthropocene: Conceptual and historical Perspectives', Philosophical Transactions of the Royal Society A 369: 842-867.

Sutcliffe, S. J. (2003) Children of the New Age: A History of Spiritual Practices. Routledge: New York.

Taylor, C. (2004) Modern Social Imaginaries. London: Duke University Press.

Veteto, J. R. and Lockyer, J. (2013) 'Environmental Anthropology Engaging Permaculture: Moving Theory and Practice Toward Sustainability' in J. Lockyer and J. R. Veteto (eds) Environmental Anthropology Engaging Ecotopia: Bioregionalism, Permaculture and Ecovillages, pp. 94-112. NY: Berghahn.

Viveiros de Castro, E. (2015) 'Who is Afraid of the Ontological Wolf? Some Comments on a Recent Anthropological Debate', The Cambridge Journal of Anthropology 33(1): $2-17$.

Vogt, K. C. (2016) 'The Post-Industrial Society: from Utopia to Ideology' Work, Employment and Society 30(2): 366-376.

Whiteman, G., Walker, B. and Perego, P. (2013) 'Planetary Boundaries: Ecological Foundations for Corporate Sustainability', Journal of Management Studies (50)2: 307-336.

Wilson, A. C. (2004) 'Reclaiming our Humanity: Decolonization and the Recovery of Indigenous knowledge'. In D. A. Mihesuah \& A. C. Wilson (Eds.), Indigenizing the academy: Transforming scholarship and empowering communities (69-87). Lincoln, NE: University of Nebraska Press.

Wolf, E. (2004) 'The Land is ours now: Spatial Imaginaries and the Struggle for Land in Brazil', Annals of the Association of American Geographers, 94(2): 409-424. 
Wright, C. and Nyberg, D. (2015) Climate Change, Capitalism and Corporations: Processes of Creative Self-Destruction. Cambridge: Cambridge University Press.

Wright, C. and Nyberg, D. (2014) 'Creative Self-Destruction: Corporate Responses to Climate Change as Political Myths', Environmental Politics 23(2): 205-223.

Wright, C., Nyberg, D., De Cock, C. and Whiteman, G. (2013) 'Future Imaginings: Organizing in Response to Climate Change', Organization 20(5): 647-658.

Wright, C. and Nyberg, D. (2012) 'Working with Passion: Emotionology, Corporate Environmentalism and Climate Change', Human Relations 65(12): 1561-1587.

Wright, E. O. (2013) 'Transforming Capitalism Through Real Utopias', American Sociological Review 78(1): 1-25.

Yusoff, K. and J. Gabrys (2011) 'Climate change and the imagination', Wiley Interdisciplinary Reviews: Climate Change, 2(4): 516-534.

Zalasiewicz, J., Williams M., Fortey R., Smith A., Barry T. L., Coe A. L. et al. (2011) 'Stratigraphy of the Anthropocene' Philosophical Transactions of the Royal Society of London A 369: 1036-1055.

Zanoni, P., Contu, A., Healy, S., and Mir, R. (2017). 'Post-capitalistic Politics in the Making: The Imaginary and Praxis of Alternative eEconomies', Organization, 24(5): 575-588. 
Table 1. Outline of Permaculture Imaginaries

\begin{tabular}{|c|c|c|c|c|c|c|c|c|}
\hline \begin{tabular}{|l|} 
Overarching \\
Manifest \\
Imaginary \\
\end{tabular} & $\begin{array}{l}\text { Predominant } \\
\text { Ethos }\end{array}$ & Locus of Inhabiting & $\begin{array}{l}\text { Ideological } \\
\text { Positioning }\end{array}$ & $\begin{array}{l}\text { Relation to } \\
\text { other } \\
\text { Initiatives } \\
\end{array}$ & Latent Imaginaries & Critical Possibilities & Key Limitations & Example \\
\hline Set of practices & Agro-ecologic & $\begin{array}{l}\text { Human as designer of } \\
\text { natural web-community }\end{array}$ & $\begin{array}{l}\text { Anarchist- } \\
\text { Libertarian }\end{array}$ & Exemplarity & $\begin{array}{l}\text { Pattern-design } \\
\text { Autonomous farming } \\
\text { Ecological } \\
\text { communities }\end{array}$ & $\begin{array}{l}\text { Ecological issues: } \\
\text { Improving agro-ecological } \\
\text { local know-how to develop } \\
\text { sustainable agricultural } \\
\text { practices and cohabitation. }\end{array}$ & $\begin{array}{l}\text { - lack of vision of } \\
\text { totality } \\
\text { - depends on existing } \\
\text { allocations }\end{array}$ & $\begin{array}{l}\text { Eartheven } \\
\text { community }\end{array}$ \\
\hline Life philosophy & Holistic-mythical & $\begin{array}{l}\text { Nature as a total } \\
\text { Interactive mythical force } \\
\text { including human and other } \\
\text { living entities }\end{array}$ & Local-Cosmic & Conversion & $\begin{array}{l}\text { Gaïa } \\
\text { Noble Savage } \\
\text { Harmony }\end{array}$ & $\begin{array}{l}\text { Environmental ethic: } \\
\text { Develop ideal of global } \\
\text { community based on careful } \\
\text { and "response-able" } \\
\text { inhabiting and a virtue } \\
\text { oriented transformation of } \\
\text { human. }\end{array}$ & $\begin{array}{l}\text {-neo-religious } \\
\text { moralism } \\
\text { - focus on unity over } \\
\text { struggle (risk of } \\
\text { struggle blindness) } \\
\text { - ideological use of } \\
\text { harmony }\end{array}$ & $\begin{array}{l}\text { The Lama } \\
\text { inter- } \\
\text { spiritual } \\
\text { foundation }\end{array}$ \\
\hline $\begin{array}{l}\text { Social } \\
\text { movement }\end{array}$ & Eco-political & $\begin{array}{l}\text { Nature as } \\
\text { context/substance of social } \\
\text { struggles along with other } \\
\text { intersectional struggles }\end{array}$ & $\begin{array}{l}\text { Local- } \\
\text { Political }\end{array}$ & Coalitional & $\begin{array}{l}\text { Resistance } \\
\text { Refuge } \\
\text { Counter-power place }\end{array}$ & $\begin{array}{l}\text { Environmental justice and } \\
\text { political inequalities: } \\
\text { Counter-balancing the } \\
\text { homogenization of } \\
\text { "Anthropos" teleologic } \\
\text { narrative by including } \\
\text { divergent and/or marginalized } \\
\text { socio-cultural narratives and } \\
\text { supporting political } \\
\text { transformation. }\end{array}$ & $\begin{array}{l}\text { - lack of power-base } \\
\text { - scale problems } \\
\text { - difficulty of finding } \\
\text { common ground }\end{array}$ & $\begin{array}{l}\text { The Kilombo } \\
\text { Permangola }\end{array}$ \\
\hline
\end{tabular}

